\title{
7 \\ (Re)Turning to Solidarity EU Economic Governance: A Normative Proposal
}

\begin{abstract}
ANA BOBIĆ
f Fter the Annual Meeting of the ESM Board of Governors on 13 June 2019, the ESM Managing Director Klaus Regling stated in a press 1 conference:

For this Annual Report, we recalculated the annual savings that Greece derives from our assistance. The number is $€ 13$ billion in savings for the Greek budget in 2018. That represents $7 \%$ of Greek GDP. And this will happen again every year. It is the largest support and largest solidarity ever given to any country in the world. ${ }^{1}$

In this sense, the principle of solidarity appears to be the cornerstone of all financial assistance: money is given from the goodness of creditors' hearts, and the solidarity they felt towards a fellow Member State in trouble. Irony aside, this statement does represent the mainstream view on solidarity in the European Union, as direct help given to a Member State in need. But for such solidarity not to be mistaken for a transfer union, measures of financial assistance have been designed to ensure the principle of equality of Member States as articulated in Article 4(2) TEU. The principle of equality of Member States prevents the development of a transfer union, for example, by prohibiting monetary financing of national budgets (Article 123 TFEU). In addition, the no-bail-out clause (Article 125 TFEU) presumes that a Member State cannot be held liable for the debt of another, as all Member States are to be treated equally. A common denominator found in these measures is that they grant absolute decision-making powers to national governments, and ultimately reduce the influence of individuals in economic governance to nothing more than national elections.

This is furthermore true given that the post-crisis economic governance is increasingly regulated through ad hoc and non-typical instruments, which
\end{abstract}

\footnotetext{
${ }^{1}$ See www.esm.europa.eu/press-releases/klaus-regling-press-conference-after-annual-meeting-esmboard-governors (emphasis added).
} 
results in both a decreased ability to use contestation fora at the EU level, as well as differentiation in terms of the variety of contestation routes and mechanisms at the national level.

In this context, judicial review carried out by national courts and the Court of Justice in EU economic governance is problematic as it departs from focusing on individual rights, instead focusing on national budgetary sovereignty. This is due to the supranational source of austerity obligations, which remain outside the realm of EU law proper, but rather in that of public international law. ${ }^{2}$ Judicial review of measures of financial assistance at the EU level was initially weak, ${ }^{3}$ stemming primarily from the fact that each of those measures had a peculiar legal status, meaning that the Court of Justice was not able to straightforwardly apply the Charter of Fundamental Rights (EUCFR). ${ }^{4}$ Admittedly, the Court of Justice appears to be changing its approach, by imposing an obligation on the Commission, when acting outside its Treaty-based functions, to ensure the EUCFR is respected. ${ }^{5}$ The same obligation is now placed on the ECB, ${ }^{6}$ and national measures implementing austerity requirements have been reviewed in limited circumstances. ${ }^{7}$

Furthermore, not all national courts have the same position and powers in their constitutional setup to review measures stemming from financial assistance programmes. For example, the German Bundesverfassungsgericht is seen as the dominant national constitutional court in the European Union, being one of the most cited courts Union-wide, and the most prominent one in questioning the decisions of the Court of Justice. ${ }^{8}$ However, the Bundesverfassungsgericht is also seen as pushing the ordoliberal agenda in EU economic policy, ${ }^{9}$ therefore depriving citizens of other Member States of having any say in the economic rationale behind governance mechanisms. This ultimately means that the extent of contestation before national courts depends on their behaviour, and their position in national legal systems. ${ }^{10}$ The fragmented state of judicial review of austerity measures prevents a more homogeneous approach towards these social conflicts.

In essence, thus, this contribution looks at the intersection between substance of the law of EU's economic governance, and the resulting procedure by which

\footnotetext{
${ }^{2}$ See, on this point, Repasi 2017: 1140.

${ }^{3}$ Case C-370/12 Pringle [2012] EU:C:2012:756. To begin with, the review of financial assistance measures based on MoUs was rejected as inadmissible. See Hinarejos 2015: 119.

${ }^{4}$ Pringle: para 180

${ }^{5}$ Joined Cases C-8/15 P to C-10/15 P Ledra Advertising [2016] EU:C:2016:701.

${ }^{6}$ Case T-107/17 Steinhoff [2019] EU:T:2019:353.

${ }^{7}$ When deciding whether to cut judges' salaries, an austerity measure introduced to meet the requirements of the bailout, the Court of Justice did not mention the ESM or any other financial assistance mechanism in the legal context of the judgment, and focused solely on the interpretation of the principle of judicial independence from Art 19(1) TEU, which it concluded was impaired by the measure in question. Case C-64/16 Associação dos Juízes Portugueses [2018] EU:C:2018:117.

${ }^{8}$ Anagnostaras 2013: 959; Kelemen 2016: 136; Mayer 2011: 757.

${ }^{9}$ Joerges 2014: 780 .

${ }^{10}$ See also Transparency International 2017: 36.
} 
EU citizens can, and should be able to, contest it. In so doing, the aim is to determine the position of the individual and her ability to make use of existing routes of judicial contestation in the current setup of EU economic governance and its normative focus on the equality of Member States. Further, it explores the roles accorded to principle of equality of Member States in the case law of the Court of Justice and national courts reviewing measures stemming from financial assistance, and offers a normative proposal for a more prominent interpretation of the principle of solidarity. In that sense, I will argue that courts are able to contribute to the resolution of austerity conflicts by reinterpreting the normative preferences of the constitutional system of the time and ensuring political equality of citizens. Methods for doing so include a teleological interpretation of rules on access to remedies and the scope of the remedies themselves.

In what follows, the second part will offer a brief description of financial assistance measures, in order to depict the influence that their versatile nature has on access to courts and the resulting judicial review. The third part will look at the judicial review of the ESM and the resulting MoUs. The fourth part will propose a normative framework of the relationship between the principles of solidarity and equality in judicial review of measures in the crisis. The final part of the chapter will conclude.

\section{LEGAL INSTRUMENTS UNDER ANALYSIS}

The number, complexity and variety of financial assistance mechanisms employed during the euro crisis is well documented in the literature. ${ }^{11}$ What binds all these instruments together is their non-typical, hybrid, ${ }^{12}$ legal nature, placed partially within and partially outside EU law, essentially transforming the well-established Treaty-based EU method of action. ${ }^{13}$ The sources considered here as instruments of financial assistance are the earlier European Financial Stabilisation Mechanism (EFSM) and the European Financial Stability Facility (EFSF), which was later replaced by the ESM. Both have been accompanied by loans provided by the IMF, as well as bilateral loans. However, to add to the complexity, the so-called 'Six-Pack'14 of EU law instruments, later replaced by

\footnotetext{
${ }^{11}$ Chiti and Teixeira 2013: 686; Kilpatrick 2014: 394; Kilpatrick 2015: 333; Poulou 2017: 995.

${ }^{12}$ Poulou 2017, 995.

${ }^{13}$ The political reasons behind these choices are also presented in detail in Chiti and Teixeira 2013: $685 \mathrm{ff}$, and will not be covered here.

${ }^{14}$ Council Directive 2011/85/EU of the Council of 8 November 2011 on the requirements for budgetary frameworks of the Member States [2011] OJ L306/41; Regulation (EU) 1173/2011 of the European Parliament and of the Council of 16 November 2011 on the effective enforcement of budgetary surveillance in the euro area [2011] OJ L306/1; Regulation (EU) 1174/2011 of the European Parliament and of the Council of 16 November 2011 on enforcement measures to correct excessive macroeconomic imbalances in the euro area [2011] OJ L306/8; Regulation (EU) 1175/2011 of the European Parliament and of the Council of 16 November 2011 amending Council Regulation (EC) No 1466/97 on the strengthening of the surveillance of budgetary positions and the surveillance and
} 
the 'Two-Pack', ${ }^{15}$ was attached to the ESM to ensure consistency between the conditionality attached to financial assistance and economic and budgetary surveillance of eurozone countries. ${ }^{16}$ These are, however, pure EU law instruments, invoking different legal consequences than an international treaty such as the ESM. What is important to note is that each of the individual instances of financial assistance has been granted as a combination of one or more of these facilities. ${ }^{17}$

The actual financial assistance to be disbursed and the conditions attached to it are negotiated between the Troika - representatives of the Commission, the ECB and the IMF - and the Member State in need of assistance. The ultimate conditions of the assistance are then agreed in a MoU, yet another instrument without a clear answer concerning its legal nature. ${ }^{18}$ The same conditions are also confirmed by a Council Decision, which, however, does not contain the same amount of detail as the MoUs. ${ }^{19}$ In sum, then, even this brief summary demonstrates the complex network of instruments in place. The way this has played out in practice before EU and national courts is presented in the following section.

\section{JUDICIAL REVIEW OF THE LEGAL INSTRUMENTS}

A feature that all national decisions concerning the ratification of the ESM Treaty share is a focus on sovereignty and more specifically on parliamentary budgetary powers as its most direct expression. ${ }^{20}$ While the ability for parliamentary involvement in decisions concerning the disbursement of aid is discussed at length in relation to the scheme of the ESM Treaty, there is hardly any mention of the Treaty's solutions concerning judicial review. This is not surprising, though: Article 37 of the ESM Treaty is the only provision concerning judicial review, solely insofar as the Court of Justice is to decide on appeals to decisions

coordination of economic policies [2011] OJ L306/12; Regulation (EU) 1176/2011 of the European Parliament and of the Council of 16 November 2011 on the prevention and correction of macroeconomic imbalances [2011] OJ L306/25; Council Regulation (EU) 1177/2011 of 8 November 2011 amending Regulation (EC) No $1467 / 97$ on speeding up and clarifying the implementation of the excessive deficit procedure [2011] OJ L306/33. The Six-Pack is available in [2011] OJ L301/1, 1-47.

${ }^{15}$ Regulation (EU) 472/2013 of the European Parliament and of the Council of 21 May 2013 on the strengthening of economic and budgetary surveillance of Member States in the euro area experiencing or threatened with serious difficulties with respect to their financial stability [2013] OJ L140/1; Regulation (EU) 473/2013 of the European Parliament and of the Council of 21 May 2013 on common provisions for monitoring and assessing draft budgetary plans and ensuring the correction of excessive deficit of the Member States in the euro area [2013] OJ L140/11.

${ }^{16}$ Poulou 2017: 995.

${ }^{17}$ Kilpatrick 2015: 336.

${ }^{18}$ For an analysis and presentation of differing views in the literature, see Markakis and Dermine 2017: 654

${ }^{19}$ Poulou 2017: 1002.

${ }^{20}$ Bardutzky and Fahey 2014: 347. 
made by the Board of Governors on the interpretation or dispute between the ESM Members. On the national level, the ESM Treaty was challenged before the highest courts ${ }^{21}$ in Austria, Estonia, France, Germany, Ireland, the Netherlands and Poland. Only the Irish case resulted in a preliminary reference to the Court of Justice concerning the compliance of the ESM Treaty with EU law, in the now famous Pringle reference. ${ }^{22}$ Resulting measures were challenged across the affected Member States. The following subsections seek to shed more light on the impact of the ESM Treaty and other legal instruments developed to manage the eurozone crisis on judicial review and the role of courts. To this end, it will provide an analysis of the ability and legal opportunities of individuals to contest the ESM Treaty and the ensuing MoUs before national courts.

\section{Access and Remedies}

This section will address the practice of Member State courts in relation to access to judicial review by individuals. Certainly, the expectation of this exercise is not to establish that the diversity of access rules on the national level immediately results in political inequality between EU citizens. This would disregard the decades of the Court of Justice's case law on national judicial autonomy, ${ }^{23}$ and would reduce the argument to full harmonisation in this area. The purpose is rather to provide an illustration of different rules on access in order to better understand the diverse thresholds in place for individuals to judicially contest decision-making in economic governance.

Individuals challenged the ratification legislation in Germany and the Netherlands. The German ratification of the ESM Treaty was subject to several constitutional complaints, one of them by a group of private citizens seeking to protect their fundamental right to vote and the ensuing parliamentary budgetary responsibility. The standard applied by the Bundesverfassungsgericht in order to admit a constitutional complaint is the 'injury to the permanent budgetary autonomy of the German Bundestag'. ${ }^{24}$ After analysing the academic criticism concerning the wide access granted to individuals in challenging measures resulting from European integration, ${ }^{25}$ the court stated that it would not change its approach, as citizens must be able to challenge the transfer of competences as a way of defending the setup of the Basic Law. ${ }^{26}$ An application for the complaint

\footnotetext{
${ }^{21}$ Depending on the national judicial systems of constitutional review, these included both supreme and constitutional courts.

${ }^{22}$ The lack of a wider engagement in the preliminary reference procedure was heavily criticised by Bardutzky and Fahey 2014: 354.

${ }^{23}$ Dougan 2004.

${ }^{24}$ BVerfG, ESM Treaty, Judgment of the Second Senate of 7 September 2011, 2 BvR 987/10, available at www.bundesverfassungsgericht.de/SharedDocs/Entscheidungen/EN/2011/09/rs20110907_2bvr 098710en.html, para 93.

${ }^{25}$ Connected to access in the Maastricht and Lisbon decisions, ibid: para 101.

${ }^{26} \mathrm{ibid}$.
} 
must be substantiated as to the erosion of the right to vote, ${ }^{27}$ and in the specific case of the ESM, when guarantee authorisations may result in 'massive adverse effects' ${ }^{28}$ for the Bundestag's budgetary autonomy. In that respect, while the access granted to individuals is wide, it is confined solely to the preservation of German-specific budgetary interests. In other words, a German citizen would not be able to challenge a measure that might have adverse effects on the stability of the eurozone as a whole, which may as well ultimately have consequences for the budgetary autonomy of the Bundestag: a measure that would be applicable only to a debtor Member State is capable of producing effects on the remainder of the eurozone members, as evidenced by the Greek sovereign debt crisis.

In the Netherlands, the ratification bill of the ESM Treaty was challenged by members of parliament acting in their capacity as private citizens ${ }^{29}$ before the Hague Civil Court. ${ }^{30}$ Importantly, one of the arguments put forward by the applicants concerned the silence of the ESM Treaty as regards judicial review and accountability. ${ }^{31}$ This is particularly relevant in the context of the Dutch constitution, which prohibits judicial review against the constitution, and is accompanied by a strong tradition of judicial self-restraint. ${ }^{32}$ Accordingly, the court in the proceedings emphasised this point by stating that it is not the appropriate forum for assessing the ESM ratification bill, as this is the role of the legislative branch. ${ }^{33}$ Importantly for the purposes of the present analysis, the court did not put forward any standards for access, but summarily addressed the main substantive points raised by the applicants.

In all other cases, the action was initiated by members of parliament (in the remainder of German decisions, Ireland), provincial government (Austria), the president (France) and the public prosecutor (Estonia and Poland). Thus, when it comes to challenging the ratification of the ESM Treaty at the national level, a clear dominance of privileged applicants is visible. It should be noted that this does not immediately deteriorate the position of the individual, as her political representatives in the legislative branch are challenging the Treaty in advance of its ratification to regulate any and all future measures of financial assistance.

Access to judicial review of individual measures stemming from financial assistance demonstrates a similar pattern. In Portugal, for example, the number of cases initiated by private individuals is not known, but the outcome of the case would not result in invalidation of a national measure, as the decisions

\footnotetext{
${ }^{27}$ ibid: para 102.

28 ibid: para 103 .

${ }^{29}$ Wilders and Others $v$ the Dutch State, case no 419556/KG ZA 12-523, Judgment in summary proceedings of 1 June 2012, available at https://uitspraken.rechtspraak.nl/inziendocument?id=ECLI :NL:RBSGR:2012:BW7242, para 2.2.

30 ibid: para 3.1 .

31 ibid: para 3.3 .

${ }^{32}$ Yein Ng 2014: 50

${ }^{33}$ Wilders and Others: para 3.3. It is important to note that Art 120 of the Dutch Constitution prohibits judicial constitutional review. See also van der Schyff 2010: 277.
} 
are binding only inter partes, ${ }^{34}$ thereby excluding more general accountability effects for decision-makers. ${ }^{35}$ Rather, all national measures challenged before the Constitutional Court were initiated by privileged applicants, such as the president, members of the legislature or regions. ${ }^{36}$ While this results in erga omnes effects of these decisions, such an outcome is only possible through indirect dependence of individuals on the constitutional organs in their Member State. In Greece, after the initial deadline for contestation before the Council of State expires, only implementing administrative acts can be challenged as regards their constitutionality, but only incidentally to the main proceedings, thereby also limiting the effects to inter partes. ${ }^{37}$ Even if the Council of State does find an administrative act unconstitutional, the precedent is not legally binding. ${ }^{38}$

Yet the interpretation of rules on access and remedies can be carried out in a teleological manner. Legal innovation, or at least a novel interpretation of access and remedies, was in fact visible on the national level. For Germany, the broad-access interpretation was introduced in the Maastricht and Lisbon decisions. In Portugal, the Constitutional Court temporarily suspended the effects of its decision when it found the budget based on new austerity measures unconstitutional. ${ }^{39}$ Therefore, it is not without basis that the courts deciding the case can take into account the specific interests that will possibly be affected by decisions stemming from economic governance. In that respect, while the approach of the German court allows individuals to trigger constitutional review of legislation, it does so only in relation to possible lessening of the budgetary powers of the Bundestag. In that sense, it would not be possible to initiate a constitutional complaint when the interests of the eurozone, or a significant portion thereof, are jeopardised due to measures of economic governance. The opposite would necessitate a dynamic approach to judicial interpretation demanding the decision-makers to justify their decisions based on Union-wide considerations. For example, in its recent decision in Weiss $I I,{ }^{40}$ the Bundesverfassungsgericht argued that the ECB did not sufficiently take into account the effects that its bond purchase programme would have on different societal groups, albeit its focus was on such groups in Germany specifically. ${ }^{41}$ However, it is impossible to carry out such an analysis without looking deeper into austerity conflicts across Member States, thereby reducing the importance of the principle of equality of Member States.

\footnotetext{
${ }^{34}$ Canotilho, Violante and Lanceiro 2015: 158.

${ }^{35}$ According to Almeida Ribeiro (2019: 4), this legal solution is arcane and departs from traditional setups of constitutional review in Europe.

${ }^{36}$ De Brito Gião Hanek and Gallo 2015: Annex I.

${ }^{37}$ Marketou and Dekastros 2015: s X.8.

${ }^{38} \mathrm{ibid}$. See also, in this volume, Lampropoulou.

${ }^{39}$ De Brito Gião Hanek and Gallo 2015: Annex I, 10.

${ }^{40}$ Cases 2 BvR 859/15, 2 BvR 980/16, 2 BvR 2006/15, 2 BvR 1651/15, Weiss II, Judgment of 5 May 2020, available at www.bundesverfassungsgericht.de/SharedDocs/Entscheidungen/EN/2020/05/ rs20200505_2bvr085915en.html.

${ }^{41}$ Bobić and Dawson 2020.
} 


\section{Interpretation of the Principle of Equality of Member States}

In what follows, the case law concerning the crisis measures will be analysed by looking at the ways in which national courts interpreted the principle of equality of Member States, and whether Union-wide considerations were of relevance. It should be added that courts have not worked explicitly with the principle of equality of Member States. Rather, as explained in the introduction, the logic of the principle of equality is found in the rules on conditionality in financial assistance, as well as in Treaty prohibition on monetary financing and the no-bail-out clause. All these aim at protecting national budgetary sovereignty, and it is this jurisprudence that is of interest here. Thus, the following analysis will look at, on the one hand, the ways in which national courts have treated conditionality and national budgetary sovereignty, and on the other hand, the stability of the entire eurozone. In order to determine the latter, special attention will be paid to whether, and if so, how, the principle of solidarity played a role in this interpretative process.

The almost universal commonality of the decisions under analysis is that sovereignty is preserved so long as the constitutionally granted powers on the national level of the legislature remain intact. The individual is only ever mentioned in this context, most prominently in the German decisions, where the right to vote, and the ensuing parliamentary budgetary sovereignty were considered a fundamental right, warranting direct interest necessary for the submission of a constitutional complaint. ${ }^{42}$ This means that the variety of societal interests forming part of austerity conflicts are conflated to a single one - that of participating in national elections. Another consequence of the focus on parliamentary budgetary responsibility is that the debate concerning the ESM focused more on the competence clashes between European Union and national level concerning fiscal policy, to the detriment of the benefits possibly stemming from a stability mechanism. This very question then placed focus on the issue of conditionality, in order to ensure that no debtor state abuses the aid given to it in times of need.

The principle of solidarity did not feature prominently in the case law of either creditor or debtor states. The German analysis in relation to the firstaid package to Greece, later reiterated in the ESM review, mentions solidarity only in the following context: 'The Bundestag must specifically approve every large-scale measure of aid of the Federal Government taken in a spirit of solidarity and involving public expenditure on the international or European Union level. ${ }^{43}$ Consequently, aid is considered an act of solidarity, and the decision does not dwell upon the importance of the aid for the stability of the eurozone

\footnotetext{
${ }^{42}$ Case 2 BVerfG 1390/12, ESM Treaty, Judgment of the Second Senate of 12 September 2012, available at www.bundesverfassungsgericht.de/SharedDocs/Entscheidungen/EN/2012/09/rs20120912_2bvr13 9012en.html, para 92.

${ }^{43}$ Case 2 BVerfG 987/10 Aids for Greece and EFSF, Judgment of 7 September 2011, www.bundesv erfassungsgericht.de/SharedDocs/Entscheidungen/EN/2011/09/rs20110907_2bvr098710en.html, para 128.
} 
as a whole. The consequences of conditionality, such as the inequality of representation and participation, therefore remain unaddressed. Rather, the insular view of each Member State concerning budgetary sovereignty prevents austerity conflicts among different societal interests to be resolved transnationally, taking into account the interdependence of the euro area.

However, the need to regard the eurozone as a common project with shared risks was present as a justification in the Greek decision of the Council of State concerning the first $\mathrm{MoU} .{ }^{44}$ More specifically, when carrying out the proportionality test concerning the cuts in salaries, benefits and pensions of public-sector employees, the Council of State found this necessary to achieve the aim of consolidating public finances, an aim in the common interest of eurozone states. ${ }^{45}$ Similarly, the Estonian Supreme Court's decision comes closer to viewing the eurozone as a risk-sharing area, and the ESM as a tool necessary for preserving its stability to the benefit of all its members: 'Estonia is a euro area Member State and therefore a threat to the economic and financial sustainability of the euro area is also a threat to the economic and financial sustainability of Estonia. ${ }^{46}$ While solidarity is not mentioned, the approach taken is one where financial aid is not simply a handout, but an investment in the prosperity of the euro area and all its members. Among creditor states, in the Dutch decision mentioned above, an important consideration was put forward by the State Secretary for Foreign Affairs, who stated that:

The interconnectedness of the Member States, and in particular of the Member States whose currency is the euro, means that economic and budgetary policies in one Member State can have disproportionate consequences for the other Member States. The consequences of not supporting the Member State can have consequences for the other Member States that are greater than the consequences for that Member State alone. ${ }^{47}$

Importantly, the Hague Civil Court deferred to this finding. ${ }^{48}$

Interestingly, in the Portuguese line of cases before the Constitutional Court, solidarity among the Portuguese people, and different regions of the country, was used as a justification for limitations of regional autonomy due to austerity measures. ${ }^{49}$ In the same vein, an 'extraordinary solidarity contribution' imposed on pension contributions was considered constitutional in line with the principle of national solidarity. ${ }^{50}$

\footnotetext{
${ }^{44}$ Decision 668/2012, 20 February 2012, available at www.dsanet.gr/Epikairothta/Nomologia/668.htm.

${ }^{45}$ Marketou and Dekastros 2015: s X.8.

${ }^{46}$ Estonian Supreme Court, Constitutional judgment 3-4-1-6-12 (ESM Treaty), 12 July 2012, available at www.riigikohus.ee/en/constitutional-judgment-3-4-1-6-12, para 165.

${ }^{47}$ Wilders and Others: para 1.9.

48 ibid: para 3.6.

${ }^{49}$ De Brito Gião Hanek and Gallo 2015: Annex I, 6, 38, 57.

${ }^{50}$ ibid: Annex I, 17, 20.
} 


\section{Interim Conclusions}

Actions initiating constitutional review concerning individual measures implementing financial assistance followed a similar trend to the review of the ESM Treaty, and have mostly been justified by recourse to the compelling public interest, which in some cases (such as Greece) included a reference to the common interest of the eurozone. Save for the case of Portugal, where the Constitutional Court attempted to safeguard social protection standards (albeit with rather limited success), it is difficult to conclude that national courts have positioned themselves as the dominant forum for contesting measures in post-crisis governance. This concerns the ability of all citizens (as opposed to institutional actors with guaranteed access to constitutional review) to access the courts as a contestation forum; as well as the ability of courts to take into account broader interests of the eurozone when interpreting measures related to financial assistance.

A final, perhaps more optimistic, remark should be made about the national case law reviewing the ESM Treaty. The courts mostly looked to each other's jurisprudence to support their findings. In that sense, the Austrian, Polish, and Estonian decisions cite earlier German findings, and the German final decision on the $\mathrm{ESM}^{51}$ in turn cites the Estonian and French decisions. While the courts did not cite each other on questions of solidarity and the necessity to regard the eurozone as a risk-sharing area, this does leave us with the impression of their awareness of a shared project, which may in the future pave the way for a more coordinated approach towards judicial contestation of economic governance.

In addition, the Irish Supreme Court was the lone institution to submit a preliminary reference to the Court of Justice in order to determine the compliance of the ESM Treaty with EU law, creating conditions for a more uniform approach of all national courts upon receiving the answer to the preliminary reference procedure. Outside the ESM Treaty, the Bundesverfassungsgericht has engaged in a preliminary reference procedure with the Court of Justice in relation to two ECB bond purchasing programmes (OMT and PSPP), 52 finding in the second decision that the ECB acted ultra vires its monetary policy mandate. ${ }^{53} \mathrm{In}$ that sense, individual national courts can act as agents promoting contestation with effects for the entire eurozone. They therefore broadly correspond to the notion of the 'public entrepreneur' introduced by Vincent Ostrom, ${ }^{54}$ representing an actor involved in the production of public goods. Presently, this concept can apply to courts as actors, achieving the public good of judicial contestation by acting on behalf of EU citizens in triggering the preliminary reference, the

\footnotetext{
${ }^{51}$ BVerfG 2 BvR 1390/12, ESM Treaty, citing the Estonian decision in paras 211, 220, and the French decision in para 244.

${ }^{52}$ BVerfG Case 2 BvR 2728/13 Gauweiler, Judgment of 21 June 2016, www.bundesverfassungsgericht.de/SharedDocs/Entscheidungen/EN/2016/06/rs20160621_2bvr272813en.html.

${ }^{53}$ BVerfG Cases 2 BvR 859/15, 2 BvR 980/16, 2 BvR 2006/15, 2 BvR 1651/15, Weiss II.

${ }^{54}$ Ostrom 1972: 2. For an analysis of the normative value of the concept of public entrepreneur in the EU context, see Kukovec 2019: $217 \mathrm{ff}$.
} 
result of which is binding on all EU Member States. In addition, submitting a preliminary reference may assuage some of the drawbacks related to access to constitutional review at the national level; namely, while access to constitutional review was guaranteed to privileged applicants, citizens, by potentially accessing the Court of Justice, may contribute to shedding light on the existence, and possible resolution, of austerity conflicts.

The preliminary reference procedure in respect of the ESM Treaty did not gain much traction before national courts given that the majority of cases concerned matters of national constitutional law. Nevertheless, the Court of Justice, although initially reluctant to admit cases concerning MoUs, gradually expanded the application of Article 267 TFEU to MoUs stemming from the EFSM and balance-of-payments assistance. ${ }^{55}$ Accordingly, it has also extended the applicability of the EUCFR, including the right to an effective remedy, to those instruments. As regards MoUs stemming from ESM assistance, the Court of Justice expanded the applicability of EU law, and consequently the EUCFR, to EU institutions when acting within the ESM framework. ${ }^{56}$ More recently, the preliminary reference procedure has been employed by the Bundesverfassungsgericht in a way that demands a higher level of justification by the ECB in conducting policies carrying high redistributive effects, and a corresponding requirement for the Court of Justice to increase its standard of judicial review. ${ }^{57}$ These are important developments, as the Court of Justice changed its approach to access and remedies, and the interpretation of the substance of obligations themselves to expand judicial protection. Ultimately, rather than providing isolated, and possibly contradictory, solutions, the preliminary reference procedure may yet result in levelling the playing field among citizens.

\section{POLITICAL EQUALITY OF CITIZENS AND CONTESTATION}

The aim of this section is to propose a reinterpretation of the principle of equality of Member States. As described and argued above, current patterns of judicial review at both the EU and the national level safeguard national budgetary autonomy and further the logic of conditionality, resulting in disparities among EU citizens in accessing courts and remedies. I will argue that a more prominent role of the principle of solidarity of EU citizens in judicial review is necessary to overcome these issues. For this purpose, I will first offer a proposal for a specific understanding of solidarity in the EMU. I will also contrast it to the principle of equality of Member States, and offer a proposal for its cosmopolitan, rather than utilitarian reading. The section will end by a brief look at how the proposed changes in interpretation can be implemented in judicial review. However, this contribution will not look into the possibility of a Treaty change

\footnotetext{
${ }^{55}$ Joined Cases C-8/15 P to C-10/15 P Ledra Advertising [2016] EU:C:2016:701.

${ }^{56}$ Case C-258/14 Florescu [2017] EU:C:2017:448.

${ }^{57}$ Dawson and Bobić 2019: 1031.
} 
in this direction, but will confine its analysis solely to judicial review and interpretative options remaining in the current legal framework. ${ }^{58}$

\section{Theorising Solidarity}

In theorising solidarity in the EU context, the literature differentiates between three levels of solidarity: between Member States, between generations, and between peoples. ${ }^{59}$ All three find expressions in different places in the Treaties, albeit without defining precisely its position as a principle. However, as McDonnell argues, solidarity should be regarded as a fundamental principle of the EU legal framework, and should guide the interpretation of provisions even where it is not explicitly mentioned. ${ }^{60}$ The literature on solidarity in the European Union corresponds to its unclear legal nature, and is most extensively addressed in the context of social rights and social policy contrasted to the imperatives of the internal market. ${ }^{61}$

In the quest to determine the role of solidarity in judicial review of the European Union's economic governance, a brief theoretical exploration of the concept of solidarity is due. Durkheim's work on solidarity provides a useful starting point, as he differentiates between mechanic and organic solidarity. ${ }^{62}$ Mechanic solidarity is present in traditionally small and homogeneous societies, and assumes help is provided on the premise that it will also be received if and when necessary as an act of altruism. Further, organic solidarity exists in modern and heterogeneous societies with a multitude of interests and interdependence, and help is provided based on 'enlightened self-interest' that guides the smooth operation of the system as a whole. ${ }^{63}$ In other words, recognition is due to the other as ethical and legal persons, and as fellow citizens both in their difference and their sameness. ${ }^{64}$ This central theoretical proposition is the starting point of theorising solidarity.

Taking Durkheim's work further, then, Honneth introduces the concept of 'social solidarity', defined as 'a felt concern for what is individual and particular about the other person', implying the recognition of 'one another in light of values that allow the abilities and traits of the other to appear significant

\footnotetext{
${ }^{58}$ Recent developments concerning the Recovery and Resilience Facility, where more significant changes of the structure of risk-sharing were proposed but rejected, have demonstrated that we will currently not witness any grand treaty reforms. Presently, thus, the judicial route remains relevant for the development of accountability in the EMU. In addition, if and when the EMU legal framework does become subject of reform, the jurisprudence in this area will most certainly have a degree of influence in devising substantive solutions. See www.consilium.europa.eu/en/policies/ eu-recovery-plan/.

${ }^{59}$ Borger 2013: 8 .

${ }^{60}$ McDonnell 2014: 61. See also Kotzur 2017: 43-44.

${ }^{61}$ See eg Barnard 2005; Menéndez 2003.

${ }^{62}$ Durkheim 1997. Durkheim's contributions are also prevalent in the existing literature concerning solidarity and the EU. See eg de Witte 2015.

${ }^{63}$ Fernandes and Rubio 2012: 3-4.

${ }^{64}$ Forst 2002: 137.
} 
for shared praxis', ${ }^{65}$ based on mutual and unconditional respect. ${ }^{66}$ Crucially, solidarity is a necessary tool for organising society according to standards that ensure equal opportunities of recognition for everyone, ${ }^{67}$ where the relationship between individuals and groups allows for 'collective interest to be served'. ${ }^{68}$ In the language of democratic theory, then, this translates to political equality of all citizens. ${ }^{69}$ Placing these theoretical contributions in the context of political organisations, the work of Dean is additionally useful. In particular, her concept of reflective solidarity relies on an outward-looking membership:

What is expected is the recognition of our interdependency and shared vulnerability, the acknowledgement of our relationship to one another. At a time of increasing globalization, (im)migration and individualization, we have both the opportunity and the need to see differences of others as contributions to and aspects of the community of all of us. Indeed, in pluralist societies the limitation of solidarity to those in our ethnos - even if we could draw such a line - threatens the very possibility of democratic discourse. ${ }^{70}$

This ultimately brings us to the work of Forst, for whom solidarity plays an important social cohesive as well as political role. For him, citizenship is the condition and the necessary expression of equality in terms of rights and taking part in a common project. ${ }^{71}$ In this respect, he underlines that 'a political community is a community of the recognition and realisation of equal rights and duties'. ${ }^{72}$ Solidarity serves the function of recognition (in the language of Honneth), a definition of membership not bound by identity ${ }^{73}$ (in the language of Dean). Importantly for the purposes of the EU context, solidarity should be used to extend, rather than narrow down, membership ${ }^{74}$ and resulting actions of solidarity. Durkheim himself found danger for solidarity in not only selfish individualism, but also nationalism of states, which he claimed can be countered by supranational integration. ${ }^{75}$

\section{Theorising Equality}

Any initial search of the term equality of states yields results from the area of public international law and the principle of sovereign equality of states. Article 2 of the UN Charter tells us that sovereign equality is the basic principle guiding

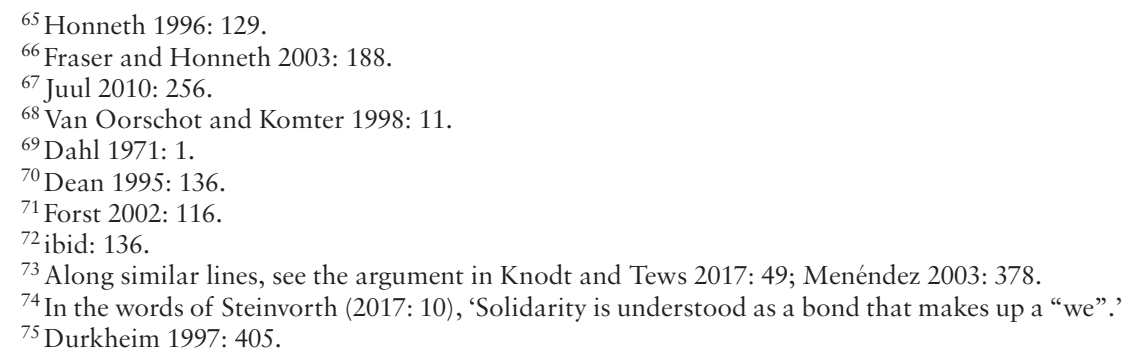


states' interactions in the international arena. Sovereign equality also means that once states sign up to a legal obligation in the international sphere, they are all equally bound to abide by it. ${ }^{76}$ As argued by Rossi, with the increase in the ability of international (and arguably, supranational) organisations to assume responsibility for carrying out the common interest of its members, the likelier it is that those members will decrease their insistence on their 'sovereign status and, correlatively, to equality'. ${ }^{77}$ The cosmopolitan literature emphasises the drawbacks that equality of states inflicts upon the equality of individuals. ${ }^{78}$ In the words of Buchanan:

$[\mathrm{P}]$ olitical equality among states is of value only so far as it contributes to justice as goal or as process. Political equality among states is not valuable for its own sake, and certainly cannot be regarded as a necessary condition in its own right for system legitimacy. ${ }^{79}$

Following Rossi, the principle of equality of Member States is merely an indicator of membership, whereas the normative aim should be one of partnership. ${ }^{80}$ In EU law, Article 4(2) TEU provides for the equality of Member States, whereas Article 9 TEU underlines the equality of citizens as the underlying obligation for all EU activities. The balance between the two principles has originally been tilted towards EU citizens, when the Court of Justice established the so-called 'Simmenthal mandate', according to which national courts must apply EU law to cases within their jurisdiction and protect the resulting rights of citizens. ${ }^{81}$ As set out in the previous section, however, judicial review of measures of economic governance on both the national and EU level was grounded in the logic of conditionality, placing the normative priority on equality of Member States. It is therefore particularly lamentable that the Court of Justice has employed this logic in its press release following the Weiss II judgment of the Bundesverfassungsgericht, where it restated the jurisprudence concerning the preliminary reference procedure, concluding: 'That is the only way of ensuring the equality of Member States in the Union they created. ${ }^{82}$ In the context of the European Union's economic governance, this approach to interpretation may lead to more emphasis being placed on conditionality, and less on the myriad of interdependencies across the entire eurozone.

\section{The Proposal for Reinterpretation of the Two Principles in Judicial Review}

I now turn to the way in which the principles of solidarity and equality can be reinterpreted by the courts, with the aim of increasing opportunities of

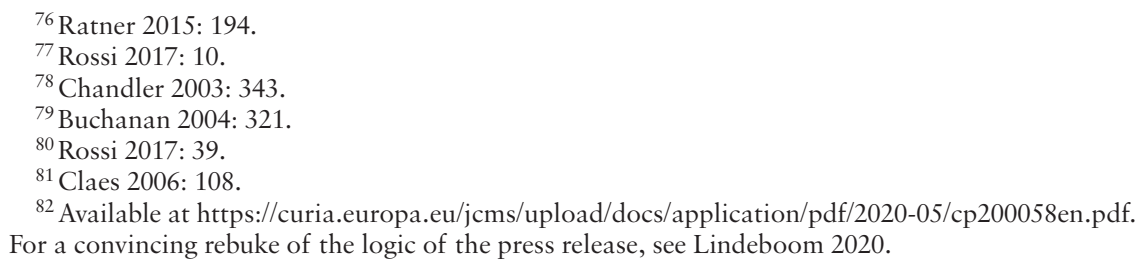

${ }^{82}$ Available at https://curia.europa.eu/jcms/upload/docs/application/pdf/2020-05/cp200058en.pdf. For a convincing rebuke of the logic of the press release, see Lindeboom 2020. 
contestation of EMU decisions for EU citizens, beyond the priority being placed exclusively the principle of equality of Member States. Applying an equilibrium between the principles of equality and solidarity in a multilevel polity, with different layers of membership (state and individual), ensures political equality among all its citizens - their ability to 'determine politically their destiny'. ${ }^{83}$ The idea behind connecting equality and solidarity seeks to overcome the use of traditional concepts such as nationality to connect citizens to commitments of justice. ${ }^{84}$ Processes of democratic accountability therefore need to provide a space for a connection between citizens, where solidarity represents the act of defining the pursuit of a shared goal, and equality ensures mutual respect among partners on the path of achieving that goal. In that sense, because the actors in place have an equal obligation of achieving the common goal defined by citizens connected through solidarity, they should be held accountable for the way they fulfil this obligation.

How do these theoretical propositions translate to the context of the European Union's economic governance? In the above theorisation of solidarity, Durkheim's work was used as an inspiration to conceive of a society connected through the respect of the dignity of the other as an inherent quality of the individual. Equality between the states was in turn theorised not as a value in itself, but only instrumental to achieving justice. In that sense, the logic of conditionality and a strict focus on equality of Member States needs to be replaced by one that takes into account the redistributive effects of EMU decisions across the entire euro area. For example, in Weiss II, the Bundesverfassungsgericht insisted that the redistributive effects on different categories of interests (eg public debt, personal savings, pension and retirement schemes, real estate prices and the keeping afloat of economically unviable companies) be assessed by the ECB. ${ }^{85}$ This demands a higher standard of justification than merely demonstrating that no Member State is asked to financially contribute more than what is due. In sum, judicial review that puts solidarity and equality on an equal footing, rather than giving preference to equality, needs to ensure that a plurality of interests and risks are taken into account, beyond the budgetary concerns of each Member State.

This approach to interpretation of the two principles promotes contestation, but in a different manner than that employed in the nation-state context because it focuses on political equality of citizens as its defining characteristic and requirement. ${ }^{86}$ Dahl defines the key characteristic of democracy as 'the continuing responsiveness of the government to the preferences of its citizens,

\footnotetext{
${ }^{83}$ Eriksen 2017: 13.

${ }^{84}$ de Witte 2015: 60.

${ }^{85}$ BVerfG Cases 2 BvR 859/15, 2 BvR 980/16, 2 BvR 2006/15, 2 BvR 1651/15, Weiss II, para 139. While the Bundesverfassungsgericht focuses on interests of German voters only, the methodology it demanded nevertheless allows the ECB to apply this logic to the entire euro area.

${ }^{86}$ See also de Búrca 2008: 130.
} 
considered as political equals'. ${ }^{87}$ Contestation is the necessary condition of political equality, given that all citizens have entrusted the institutions to pursue and achieve the goals in the common interest.

There are at least three main areas of judicial action through which courts can act on behalf of citizens in holding decision-makers to account in order to ensure a balanced application between the principles of solidarity and equality. First, through a teleological interpretation of the relevant legal framework, the courts are able to control the scope of access. For example, Article 263 TFEU regulates access for direct action and requires that the applicant be directly and individually concerned by the act under review, or only directly concerned when the act under review does not require further implementing measures. ${ }^{88}$ If we understand the EMU as a solidarity area where decision-makers act in the interest of all citizens equally, and where the effects of these decisions (eg resulting in austerity measures at the national level) lead to more immediate effects to a broad group of citizens, there is space for the concept of 'direct concern' to be interpreted more broadly when interpreting access conditions. For example, the effects-based review that courts employed in the financial crisis ${ }^{89}$ may well be used to interpret the direct concern requirement necessary to trigger access to justice.

Second, judicial remedies are not static legal instruments withstanding the demands created by societal realities. In its recent decision in Rimševičss, ${ }^{90}$ the Court of Justice invalidated a national measure when applying the statutes of the European System of Central Banks (ESCB) and of the ECB. ${ }^{91}$ The Court justified the decision by underlining the independence of the $\mathrm{ECB}$, and entered for the first time unchartered territory: annulling a national measure. The relevant provision of the statutes provides for a referral to the Court of Justice, but nowhere explicitly allows annulling a national measure. It is important to note that different language versions of Article 14.2 of the ESCB statutes open up space for further procedural ambiguity ${ }^{92}$ leaving space open for debate whether it can be considered analogous to the annulment procedure from Article 263 TFEU, and even more so, whether such an analogy can be extended to national measures. Nevertheless, it is through the interpretation of the purpose of this provision that the Court found the legal justification for its action. ${ }^{93}$ In addition, the Bundesverfassungsgericht in Weiss II employed a temporary remedy, providing the Bundesbank with a three-month period to ensure that the $\mathrm{ECB}$

\footnotetext{
${ }^{87}$ Dahl 1971: 1.

${ }^{88}$ See Case T-18/10 Inuit [2011] EU:T:2011:419 and Case T-262/10 Microban [2011] EU:T:2011:623.

${ }^{89}$ Steinbach 2017: 254.

${ }^{90}$ Joined Cases C-202/18 and C-238/18 Rimšèvičs [2019] EU:2019:139.

${ }^{91}$ For a comment on the novelties of the case, see Hinarejos 2019: 1649.

${ }^{92}$ The analysis compared Art 14(2) ESCB Statute in EN, FR, IT, HR, SLO, BG, CZ, PL, and SK. The variety of procedural solutions include: a referral (EN), an appeal (FR, PL, CZ), or simply an initiation or a proposal of a procedure (IT, HR, SLO, BG, SK) before the Court of Justice.

${ }^{93}$ Joined Cases C-202/18 and C-238/18 Rimšêvičs, paras 45-48.
} 
had in fact taken a plurality of interests into account when rolling out its PSPP programme. $^{94}$

A rethinking of remedies is thus not beyond the powers of the courts, and can be used in furthering the normative aim of political equality of citizens and the stability of the entire eurozone. The decisions in Rimševičs and Weiss II demonstrate that procedural solutions are not static and may develop in order to remedy shortcomings of a conditionality-driven logic of decision-making in EU economic governance.

Finally, even without interfering in the structure of remedies formally prescribed, the courts are still able to enforce the obligation of decision-makers to act in the interest of the entire interdependent euro area. The grounds for reviewing administrative action, such as the duty to state reasons or legality may be used to ascertain the interests pursued by the decision under review, as well as to determine standards of necessity in proportionality review. In sum, courts, as institutions created and designed with the purpose of safeguarding the rights and interests of all citizens equally, are in the position to ensure democratic contestation.

\section{CONCLUSION}

In this chapter I have tried to propose a new understanding of the principles of equality and solidarity in EU economic governance and suggest that they be given equal importance in judicial review of financial assistance measures. As explained in the previous section, an approach involving increased emphasis on solidarity in comparison to the status quo would result in a more egalitarian relationship between EU citizens, thus contributing to their equal ability to contest decision-making in EU economic governance.

But what does this mean for the individual and her ability to challenge bailout conditions in a way that is more concrete than participation in national elections? What platform grants all EU citizens political equality, and can take into account the benefits of the application of solidarity in practice, taking into account the health of the entire eurozone, as well as of the entire European Union? It is more than obvious that national elections cannot provide a platform for challenging individual austerity measures attached to bailout conditions, and their very nature strives to mechanic solidarity, rather than solidarity based on the pursuit of the common good. Equally, in creditor countries, the same approach raises similar problems: a discourse of blaming individual Member States without taking responsibility for the entire bloc leads to fragmentation, and furthering of inequalities in political rights of EU citizens when it comes to the design and application of financial assistance measures.

\footnotetext{
${ }^{94}$ BVerfG Cases 2 BvR 859/15, 2 BvR 980/16, 2 BvR 2006/15, 2 BvR 1651/15, Weiss II, para 235.
} 
Judicial review that puts solidarity and equality on an equal footing, rather than favouring equality, needs to ensure that a plurality of interests and risks are taken into account, beyond the budgetary concerns of each Member State. Regarding the eurozone as an interdependent area creating opportunities of economic advancement of all its citizens is necessary to overcome debtor-creditor polarisation, and ultimately promote equality of citizens.

\section{REFERENCES}

Almeida Ribeiro, G (2020) 'Judicial Review of Legislation in Portugal: A Brief Genealogy' in F Biagi, J O Frosini and J Mazzone (eds), Constitutional History: Comparative Perspectives (Leiden, Brill).

Anagnostaras, G (2013) 'Activation of the Ultra Vires Review: The Slovak Pensions Judgment of the Czech Constitutional Court' 14 German Law Journal 959.

Bardutzky, S and Fahey, E (2014) 'Who Got to Adjudicate the EU's Financial Crisis and Why? Judicial Review of the Legal Instruments of the Eurozone' in M Adams, F Fabbrini and P Larouche (eds), The Constitutionalization of European Budgetary Constraints (Oxford, Hart Publishing).

Barnard, C (2005) 'EU Citizenship and the Principle of Solidarity' in E Spaventa and $M$ Dougan (eds), Social Welfare and EU Law (Oxford, Hart Publishing).

Bobić, A and Dawson, M (2020) 'Making Sense of the "Incomprehensible": The PSPP Judgment of the German Federal Constitutional Court' 57 CML Rev 1953.

Borger, V (2013) 'How the Debt Crisis Exposes the Development of Solidarity in the Euro Area' 9 European Constitutional Law Review 7.

Buchanan, A (2004) Justice, Legitimacy, and Self-Determination: Moral Foundations for International Law (Oxford, Oxford University Press).

Canotilho, M, Violante, T and Lanceiro, R (2015) 'Austerity Measures under Judicial Scrutiny: The Portuguese Constitutional Case-law' 11 European Constitutional Law Review 155.

Chandler, D (2003) 'New Rights for Old: Cosmopolitan Citizenship and the Critique of State Sovereignty' 51 Political Studies 332.

Chiti, E and Teixeira, PG (2013) 'The Constitutional Implications of the European Responses to the Financial and Public Debt Crisis' 50 CML Rev 683.

Claes, M (2006) The National Courts' Mandate in the European Constitution (Oxford, Hart Publishing).

Dahl, RA (1971) Polyarchy: Participation and Opposition (New Haven, CT, Yale University Press).

Dawson, M and Bobić, A (2019) 'Quantitative Easing at the Court of Justice - Doing Whatever it Takes to Save the Euro: Weiss and Others' 56 CML Rev 1005.

Dean, J (1995) 'Reflective Solidarity' 2 Constellations 114.

De Brito Gião Hanek, R and Gallo, D (2015) Constitutional Change through Euro Crisis Law: Report of Portugal, available at https://eurocrisislaw.eui.eu/wp-content/uploads/ sites/44/2019/05/Portugal.pdf.

de Búrca, G (2008) 'Developing Democracy Beyond the State' 46 Columbia Journal of Transnational Law 101.

de Witte, F (2015) Justice in the EU: The Emergence of Transnational Solidarity (Oxford, Oxford University Press). 
Dougan, M (2004) National Remedies Before the Court of Justice Issues of Harmonisation and Differentiation (Oxford, Hart Publishing).

Durkheim, E (1997) The Division of Labour in Society (New York, Free Press).

Eriksen, EO (2017) 'Structural Injustice: The Eurozone Crisis and the Duty of Solidarity' ARENA Working Paper 4/2017.

Everson, M (2015) 'An Exercise in Legal Honesty: Rewriting the Court of Justice and the Bundesverfassungsgericht' 21 European Law Journal 474.

Fernandes, S and Rubio, E (2012) 'Solidarity within the Eurozone: How Much, What For, For How Long?' Notre Europe Policy Paper 51.

Forst, R (2002) Contexts of Justice: Political Philosophy beyond Liberalism and Communitarianism (Berkeley, University of California Press).

Fraser, N and Honneth, A (2003) Redistribution or Recognition? A Political-Philosophical Exchange (London, Verso).

Hinarejos, A (2015) 'The Role of Courts in the Wake of the Eurozone Crisis' in M Dawson, $\mathrm{H}$ Enderlein and C Joerges (eds), Beyond the Crisis. The Governance of Europe's Economic, Political, and Legal Transformation (Oxford, Oxford University Press).

Hinarejos, A (2019) 'The Court of Justice Annuls a National Measure Directly to Protect ECB Independence: Rimšêvičs' 56 CML Rev 1649.

Honneth, A (1996) The Struggle for Recognition: The Moral Grammar of Social Conflicts (Cambridge MA, MIT Press).

Joerges, J (2014) “"Brother, Can You Paradigm?”' 12 ICON 772.

Juul, S (2010) 'Solidarity and Social Cohesion in Late Modernity: A Question of Recognition, Justice and Judgement in Situation' 13 European Journal of Social Theory 253.

Kelemen, RD (2016) 'On the Unsustainability of Constitutional Pluralism. European Supremacy and the Survival of the Eurozone' 23 Maastricht Journal of European and Comparative Law 136.

Kilpatrick, C (2014) 'Are the Bailouts Immune to EU Social Challenge Because They Are Not EU Law?' 10 European Constitutional Law Review 393.

Kilpatrick, C (2015) 'On the Rule of Law and Economic Emergency: The Degradation of Basic Legal Values in Europe's Bailouts' 35 OJLS 325.

Knodt, M and Tews, A (2017) 'European Solidarity and its Limits: Insights from Current Political Challenges' in A Grimmel and S My Giang (eds), Solidarity in the European Union. A Fundamental Value in Crisis (New York, Springer).

Kotzur, M (2017) 'Solidarity as a Legal Concept' in A Grimmel and S My Giang (eds), Solidarity in the European Union. A Fundamental Value in Crisis (New York, Springer).

Kukovec, D (2019) 'Peaceful Contestation' in J van Zeben and A Bobić, Polycentricity in the European Union (Cambridge, Cambridge University Press).

Lindeboom, M (2020) 'Is the Primacy of EU Law Based on the Equality of the Member States? A Comment on the CJEU's Press Release Following the PSPP Judgment' 21 German Law Journal 1032.

Markakis, M and Dermine, P (2017) 'Bailouts, the Legal Status of Memoranda of Understanding, and the Scope of Application of the EU Charter: Florescu' 55 CML $\operatorname{Rev} 643$.

Marketou, AI and Dekastros, M (2017) Constitutional Change through Euro Crisis Law: Report of Greece, available at http://eurocrisislaw.eui.eu/country/greece/.

Mayer, FC (2011) 'Rashomon in Karlsruhe: A Reflection on Democracy and Identity in the European Union: The German Constitutional Court's Lisbon Decision and the Changing Landscape of European Constitutionalism' 9 ICON 757. 


\section{Ana Bobić}

McDonnell, A (2014) 'Solidarity, Flexibility and the Euro-crisis. Where Do Principles Fit In?' in LS Rossi and F Casolari (eds), The EU after Lisbon: Amending or Coping with the Existing Treaties? (New York, Springer).

Menéndez, A J (2003) 'The Sinews of Peace: Rights to Solidarity in the Charter of Fundamental Rights of the European Union' 16 Ratio Juris 374.

Ostrom, V (1972) 'Polycentricity' (Part 1), reprinted in M D McGinnis (ed), Polycentricity and Local Public Economies: Readings from the Workshop in Political Theory and Policy Analysis (University of Michigan Press 1999).

Poulou, A (2017) 'Financial Assistance Conditionality and Human Rights Protection: What Is the Role of the EU Charter of Fundamental Rights?' 54 CML Rev 991.

Ratner, SR (2015) The Thin Justice of International Law (Oxford, Oxford University Press).

Repasi, R (2017) 'Judicial Protection against Austerity Measures in the Euro Area: Ledra and Mallis' 54 CML Rev 1123.

Rittberger, B (2014) 'Integration without Representation? The European Parliament and the Reform of Economic Governance in the EU' 52 Journal of Common Market Studies 1174.

Rossi, LS (2017) 'The Principle of Equality Among Member States of the European Union' in L S Rossi and F Casolari (eds), The Principle of Equality in EU Law (New York, Springer).

Steinbach, A (2017) 'Effect-based Analysis in the Court's Jurisprudence on the Euro Crisis' 42 EL Rev 254.

Steinvorth, U (2017) 'Applying the Idea of Solidarity to Europe' in A Grimmel and S My Giang (eds), Solidarity in the European Union. A Fundamental Value in Crisis (New York, Springer).

Tomkin, J (2013) 'Contradiction, Circumvention and Conceptual Gymnastics: The Impact of the Adoption of the ESM Treaty on the State of European Democracy' 14 German Law Journal 169.

Transparency International (2017) From Crisis to Stability. How to Make the European Stability Mechanism Transparent and Accountable, available at https://transparency. eu/wp-content/uploads/2017/03/ESM_Report_DIGITAL-version.pdf.

van der Schyff, J (2010) 'Constitutional Review by the Judiciary in the Netherlands: A Bridge Too Far?' 11 German Law Journal 175.

Van Oorschot, W and Komter, A (1998) 'What Is It That Ties ... ? Theoretical Perspectives on Social Bond' 41 Sociale Wetenschappen 4.

Vranes, E (2013) 'German Constitutional Foundations of, and Limitations to, EU Integration: A Systematic Analysis' 14 German Law Journal 75.

Weiler, JHH (1995) 'Does Europe Need a Constitution? Demos, Telos and the German Maastricht Decision' 1 European Law Journal 219.

Yein Ng, G (2014) 'Judicialisation and the End of Parliamentary Supremacy: Shifting Paradigms in the Protection of the Rule of Law and Human Rights in the UK, France and the Netherlands' 3 Global Journal of Comparative Law 50. 